\title{
Tourism and Southeast Asian rural livelihood trajectories: the case of a large work integration social enterprise in Siem Reap, Cambodia
}

\author{
Robin Biddulph* \\ Human Geography Unit, University of Gothenburg, Sweden
}

Livelihoods in rural Southeast Asia are widely divergent, but often characterized by a reduced role for agriculture and local natural resources. The diverse components of an expanding tourism industry can provide opportunities for rural households seeking more diversified livelihood strategies. Artisans Angkor is a tourism social enterprise employing over 800 artisans in rural Cambodia. This study analysed the benefits of formal employment with Artisans Angkor by studying one village where six long-term Artisans Angkor employees lived, and comparing their situations with those of their direct peers. While income levels were often similar, significant benefits related to safe working conditions, social insurance and above all enabling young households to live together at home. This study provides insights into how qualitative research can contribute contextualized understandings of tourism employment's livelihood effects.

Keywords: social enterprise, tourism, rural livelihoods, Southeast Asia, Siem Reap

\section{INTRODUCTION}

The rapid expansion of tourism into less developed country settings in recent decades has generated substantial economic, social and environmental impacts. Finding ways to ensure that these impacts can be harnessed in ways that are inclusive and pro-poor continues to be a key concern for tourism research (see for example Bakker/Messerli 2017; Mitchell/Ashley 2010; Scheyvens/Biddulph 2018; Sharpley 2016). In recent years a new institutional form, tourism social enterprises (TSEs), has emerged and begun to attract research interest. Whilst commercial tourism enterprises are primarily oriented to profit-making (albeit sometimes with substantial corporate social responsibility orientation), social enterprises are primarily justified by an orientation towards making a positive social or environmental impact in host communities (von der Weppen/Cochrane 2012).

Early TSE research has focused on organizational forms and effectiveness (Dahles et al. 2020; von der Weppen/Cochrane 2012) or conceptual frameworks (Aquino et al. 2018). As such it has tended not to focus empirically on the social impacts of the enterprises, but has instead used the winning of international awards (von der Weppen/Cochrane 2012) or successful establishment in tourism markets (Biddulph 2018) to identify cases and has thus to some degree taken industry reports of social

* Email: Robin.Biddulph@geography.gu.se. 
benefits at face value. This study complements those more conceptually and organizationally oriented approaches by seeking to understand the benefits of a TSE at an individual, household and community level. As such, the aim of this article is to understand the employment impacts of a TSE in the context of the existing lives and livelihoods in workers' home communities.

In the two decades since peace returned to the province, Siem Reap in northwest Cambodia has become a booming tourist destination. The Angkor Wat temple complex, distributed in the countryside north and northeast of the provincial town, is Cambodia's main tourism attraction. In 1998, the year that the death of Pol Pot finally marked an end to three decades of civil war, genocide and guerilla insurgency, the country received only 118000 visitors. Twenty years later, in 2018, over six million international tourists visited the country (Ministry of Tourism 2019). While this tourism boom has transformed Siem Reap town and has contributed significantly to the national economy (Sharpley/McGrath 2017), its impacts on rural areas of the province have been limited (Biddulph 2015; Mao et al. 2014; Winter 2008). Artisans Angkor is a social enterprise that was established in order to both revive traditional handicrafts during the post-conflict period, and also to employ 800 artisans in order to 'empower them to create opportunities for a better life' (Artisans Angkor 2020). By employing its artisans in 48 workshops distributed throughout the Siem Reap countryside Artisans Angkor has sought to distribute the benefits of tourism employment beyond the immediate vicinity of Siem Reap town.

In order to study the social impacts of Artisans Angkor on its workers and their communities I conducted a case study of a village that I first stayed in during the 1990s and which I have visited regularly since 2012. Six Artisans Angkor employees, three men and three women, lived in the village, and I sought to understand how their work with Artisans Angkor fitted with their other obligations, and with the livelihood activities of fellow household members. I introduced a comparative element by asking each of the employees to identify a friend who they had gone to school with, and who had a similar background and abilities to them, who I could also interview.

If we are to understand the impacts of tourism we need to understand the contexts in which those impacts occur. By adopting a livelihoods approach, this study contributes to an understanding of what difference tourism employments make to both the employees and to others in their communities. As such, it also contributes to the development of grounded expectations of what potentials employment in the tourism industry in general, and tourism social enterprises in particular, might offer especially in rural settings of less developed countries.

\section{LITERATURE REVIEW: RURAL LIVELIHOODS AND TOURISM SOCIAL ENTERPRISES}

\subsection{Tourism and rural livelihood trajectories in Southeast Asia}

In rural settings in less developed countries, conventional economic measures such as employment and income often have limited meaning. People gain a living through a variety of activities, some of which are not monetized and very few of which constitute a formal employment registered in official statistics. It was for this reason that a livelihoods approach was developed during the 1980s and became widespread in rural research in the decades that followed (Chambers/Conway 1992). Livelihoods research focuses on the situations, resources and strategies of the poor. Sustainability has always been a key concern for livelihoods researchers and focuses on households' 
ability to adapt to shifting circumstances, including seasonal differences, and to cope with stresses and shocks, as well as with issues of local resource conservation and the possibilities for future generations (Chambers/Conway 1992: 6; De Haan/Zoomers 2005: 40; Scoones 1998).

Livelihoods research is linked to participatory traditions that value local knowledge. For the likes of Chambers, a focus on local agency and resources was also an invitation to build policy not on external expertise but on the analyses and the practical responses of the poor (Chambers 1997; Shen et al. 2008). In practice, livelihoods research has become widely practised, with standard frameworks introduced, often incorporating a conceptualization of people's assets in terms of five 'capitals' human, social, physical, financial and natural (Scoones 1998) - which in some cases has led researchers to adopt more survey-style, extractive quantitative methods (see for example Kausar/Nishikawa 2010).

A major contribution of livelihoods researchers has been to highlight the ways in which rural livelihoods in Southeast Asia (and beyond) have become more varied and dynamic. It is increasingly likely that some members of rural households in southeast Asia are living and working away from home, or that they are living at home but working outside the village; agriculture's share in these multi-sited household livelihood strategies is therefore often of decreasing importance (see for example Rigg 2015; Rigg/Salamanca 2017). Tourism researchers have used livelihoods approaches to explore the role that tourism might play in the context of these shifts in rural livelihoods. This has included explorations of a wide variety of contexts, including: the integration of Hmong communities into wider economies in Vietnam (Turner 2012); decreasing fishing yields for coastal communities in the Philippines (Fabinyi 2010); a more sudden extinguishing of fishing possibilities in coastal Indonesia (Lasso/Dahles 2018); forest transitions around Luan Prabang in northern Laos (Newby et al. 2014); the shifting post-conflict rural landscape in Cambodia (Biddulph 2015); and land-use restricted conservation zones in Indonesia (Kausar/Nishikawa 2010).

This existing literature makes it clear that tourism will not constitute a magic bullet that compensates for restricted access to a declining natural resource base. In some cases tourism only seems to offer limited opportunities to relatively few households (Biddulph 2015; Fabinyi 2010), while in others it does seem to provide useful options for some individuals and households (Newby et al. 2014; Turner 2012). However, where tourism becomes a dominant livelihood this raises concerns relating to both tourism's seasonality and its vulnerability to external factors such as security concerns and infectious diseases (Baker/Coulter 2007; Lasso/Dahles 2018). In keeping with the focus on local agency and knowledge, analyses are grounded in local people's perspectives. Some of Fabinyi's (2010) fisher respondents had benefited from tourism, but nevertheless did not aspire to more tourism-oriented livelihoods largely because they feared increased involvement from predatory local authorities. They therefore preferred to look for ways of increasing their fishing yields, notwithstanding the already declining stocks. By contrast, Turner's (2012) respondents, Hmong women working directly in tourism as trekking guides or indirectly as producers and traders of textiles, were less outspoken. Nevertheless, in the active choices they made to not allow their lives and livelihoods to be dominated by tourism, Turner discerned a form of quiet resistance.

Livelihoods researchers who have looked at the role of tourism in rural areas of Southeast Asia have therefore not only highlighted the ways in which tourism livelihood activities need to fit with existing livelihood strategies (cf. Tao/Wall 2009), 
but also emphasized that tourism, like agriculture and fishing, comes with its own seasonalities and vulnerabilities, and that these may not always match with the needs and aspirations of rural households.

\subsection{Social enterprises in the tourism sector}

Social enterprises in the tourism industry are a relatively new phenomenon that is starting to receive research attention (Sheldon/Daniele 2017). Social enterprises are hybrid businesses that have both a commercial orientation and a social mission. Most definitions stress the primacy of the social objective, sometimes by stipulating that some or all of the profits must be reinvested in the social objective or in the business, see for example Chell et al. (2010: 486). A useful refinement is provided by the Overseas Development Institute in the UK, which stipulates that a social enterprise's business mission must to some degree be compromised by its social mission (Smith/ Darko 2014: 3). Importantly, this trade-off means that a business which carefully calibrates its social activities to deliver maximum profits (what some might term 'pink-washing') would not be considered a social enterprise.

Dry definitions of social enterprise as a hybrid organizational form do not do justice to the extent to which social enterprises are part of an inspirational movement. This envisions a new sector which will overcome the limitations of the traditional public, private and voluntary sectors by bringing private-sector approaches and a sense of mission to social problems (see for example Dees 2008). Social enterprises are anticipated as being able to harness innovation to good business practice in order to achieve large-scale change (Kickul/Lyons 2016). Iconic examples of innovative social enterprises that have achieved scale are cited, especially Mohamad Yunus's innovation of group-secured loans which grew from a single loan in a Bangladeshi village to become an international phenomenon (Desa/Koch 2014; Yunus et al. 2010). Some researchers have raised the concern that this messianic view of the social entrepreneur risks producing a grand narrative that focuses on a heroic social entrepreneur and their qualities, whilst presenting a simplified view of the social world as rather malleable and amenable to reform (Dey/Steyaert 2010). Whilst the social entrepreneurship literature includes more socially and politically nuanced discussions (see for example Nicholls/Teasdale 2017; Saebi et al. 2018), Dey/Steyaert's (2010: 94) exhortation to beware of 'de-historicized and de-contextualized' narratives remains relevant. Academic research that attends to the context of social enterprises provides a valuable counter to such narratives.

Early research encounters with TSEs have occasionally found, and warned against, the entrepreneur-centred narratives that Dey/Steyaert warned of (Mody/Day 2017). However, whilst some authors have focused more on the entrepreneurs and how the businesses work (Biddulph 2018; von der Weppen/Cochrane 2012), for other tourism researchers the promise of social enterprise is quite different. Aquino et al. (2018) in particular envisage social enterprise as a means to empower local communities. They develop a framework that involves social entrepreneurs working as community organizers, strengthening solidarity and agency within the community, as well as sharing their networks in the tourism industry, thereby enabling the local community to coalesce as an effective corporate tourism actor. In common with the heroic/ messianic social entrepreneur literature, this approach to social enterprises stresses social innovation. However, the concern here is less with finding innovations that will 'jump scale' in the way that Yunus's group-secured loans did, and more with the sort of innovations that are required to enable a community to engage effectively with and 
in the tourism sector. Aquino et al. (2018), and others sharing their perspective, have seen the sustainable livelihoods framework as a useful way of analysing possibilities and outcomes, whether in sketching out broad conceptual frameworks for understanding TSE potentials (Shen et al. 2008), or in empirical case studies (see for example Laeis/Lemke 2016).

The degree and nature of community engagement achieved by TSEs was also the main concern of a recent study of 16 TSEs in Cambodia (Dahles et al. 2020). Engaging inductively with the cases, the authors derived a typology of three sorts of engagement: a 'cash cow model' where the community benefits from tourism but is not engaged with it; a 'community empowerment model' which consciously focuses on mutual learning between tourists and host communities in settings such as community-based tourism, but which is still somewhat externally steered and donordependent; and an 'inclusive business model' where new initiatives focus on both addressing social or environmental problems and doing so in such a way as local people are able to take the lead as employers rather than employed. Whilst finding some promise, especially in the fact that the inclusive business model cases included young, educated Cambodian entrepreneurs and not just ex-patriates, the overall verdict was rather sober. The authors found that the impacts of these TSEs were rather marginal, and liable to be lost if tourism numbers declined.

The existing literature on tourism social enterprises, then, remains somewhat undeveloped. A lot of it represents initial attempts to find appropriate theories, concepts and frames of reference, with more focus thus far on the enterprises and their approaches than on their effects. At this point, the dominant interest is in TSE potential to drive community development in the destination. This article complements the existing literature by providing a perspective from individuals and households within a local community, rather than regarding the community as a whole as an object for development.

\section{MATERIALS AND METHOD}

\subsection{Research paradigm}

Livelihoods research is predicated on the assumption that the ways in which people in less developed settings make a living are not easily reduced to simple measures of income and employment. An approach is required that is attentive to the ways in which people make choices and develop portfolios of activities in the context of complex social and physical dynamics that are not easily understood by outsiders. Qualitative case study research that focuses on household decision-making and its context is a response to that challenge. Case study research enables the significance of specific, concrete phenomena to be generalized as a 'case of' something through the application of concepts and the identification of patterns, which may lead to results that have theoretical implications (Lund 2014). In this study, an exploration of the specific, concrete impacts of working for the TSE Artisans Angkor in Doun On village are explored as a case of tourism impacts on rural livelihoods in Southeast Asia.

The use of semi-structured interviews enabled information to be cross-checked and verified, and also allowed inductive responses to new insights which emerged (Ren 2016). Compared with quantitative survey methods, this paradoxically enhances not only the voice of the respondents, but also the role of the researcher. A villager who strategically conceals some income sources in order to appear poorer than they really are can easily do so if the researcher must follow pre-formulated survey questions 
administered in a standardized interview format (see Biddulph 2010: 177 for previous experience of this in Cambodia). Given that villagers may well assume (researchers' protests notwithstanding) that research is a prologue to welfare or development interventions, this ability to cross-check and triangulate can be key.

\subsection{Studying a familiar village}

Doun On village is about one hour from Siem Reap town by motorcycle. It is located in Don Keo commune, about $10 \mathrm{~km}$ northeast of Pouk district town, and $10 \mathrm{~km}$ north of the Western Baray reservoir. It was chosen because it is the village in Siem Reap where Artisans Angkor workers live that is most familiar to me. This was in order to maximize the chances of achieving an adequate understanding of the context for the study. It was also to maximize the chances of villagers being able to respond in a comfortable and honest way. There are many reasons for Cambodian villagers to be fearful of outsiders asking questions. I worked with a research associate, Ms Ly Sinath, who is an education official from a different district in Siem Reap, and therefore less of an outsider than myself (I therefore use the first person plural for describing the field work where I was accompanied and advised by Sinath). We had been known by many villagers for 20 years, and their experience of us has been that neither gifts nor retribution follows our visits. This increased the chances of open, honest exchanges in our interviews.

I lived in Cambodia from 1991-2001 and speak fluent Khmer. I first encountered the village when doing policy research into local governance, staying in Doun On village in 1997 and returning for a week each in 1998 and 1999. I had two further week-long stays in the village in February and October 2012 doing research into tourism and livelihoods. The first 2012 visit included a 100 per cent survey of villagers' livelihoods and the second comprised in-depth qualitative interviews. Since then, I have conducted research (as yet unpublished) with migrants from Doun On who have migrated to Siem Reap town. I have returned regularly to Doun On to visit them and their families during that time. My research associate Sinath - a native Khmer speaker born in another district of Siem Reap who had spent 30 years working in rural villages - was also part of the research teams in 1998, 2012 and many of the more recent visits. We were therefore participating in a research tradition which allows valuable longitudinal perspectives and a greater degree of intimacy and insight than would be obtained by one-off studies of unfamiliar places (cf. Blaikie et al. 2002; Rigg/Salamanca 2017).

Doun On has 250 households, five of which contain Artisans Angkor workers. In order to update ourselves on developments in village livelihoods since 2012 we interviewed villagers with recent experience of key livelihood activities, especially construction in Siem Reap, migrant work in Thailand and wet season migration to the flood plains of the great Tonle Sap lake (see Section 4 and Appendix 1).

\subsection{Household livelihoods in comparative perspective}

Interviews were conducted with all six of the Artisans Angkor employees living in the village. Each of them was asked to nominate an old school friend who had a similar family background and who had studied to the same level. Five of the six respondents were able to nominate such a peer. It transpired that two of the Artisans Angkor workers (SW3/SW4) were a married couple, so the six employees belonged to five different households. The other four employees were two pairs of siblings (SW1/ 
SM5; SW2/SM6). In addition to interviewing the workers and their peers we also interviewed the parents/parents-in-law of four of the employees (see Table 1). The use of multiple sources - the workers, their peers, their family members and other key informants - meant that each livelihood and livelihood activity was discussed from multiple viewpoints enabling triangulation of statements and a high level of confidence in our results.

We interviewed people at home. I explained the research to them and sought their permission to record the interviews before beginning. I conducted the interviews with the research associate interjecting if she thought there were misunderstandings or if the interviewee struggled to respond. We also discussed the content of interviews during the day and in the evening as part of the iterative process of data collection and analysis. The interview questions recapped the life stories, household constellations and ways of making a living from the time they finished their education up to the time of the interview. All respondents were then asked to make comparisons between working for Artisans Angkor and not working for Artisans Angkor. An open question, 'Which is better?', was then followed by questions about the reasons why certain employments or activities were preferred.

Of the 19 interviews conducted during our five-day stay in the village, 14 were successfully recorded and transcribed. Thematic analysis was conducted with a mixture of deductive and inductive coding (Terry et al. 2017), the main themes being identified in advance whereas some sub-themes were identified inductively during the analysis. The four main themes were: (1) Livelihood activities (10 sub-themes); (2) Benefits of working for Artisans Angkor (8 sub-themes); (3) Comparisons made between working for Artisans Angkor and other work (5 sub-themes); and (4) Livelihoods concepts (8 sub-themes). Analysis was done manually with numbers (for themes) and letters (for sub-themes) used to mark up the text. The livelihoods concepts were focused on temporal variation (trajectories/seasonal variation/shocks), strategies (diversification/migration/intensification) as well as 'fit' between different activities and 'aspirations'.

Table 1 Artisans Angkor employees and peers in the study sample

\begin{tabular}{lcccccc}
\hline Code & Pseudonym & $\begin{array}{c}\text { Age in } \\
2017\end{array}$ & Sex & $\begin{array}{c}\text { Year } \\
\text { began } \\
\text { work with } \\
\text { Artisans } \\
\text { Angkor }\end{array}$ & $\begin{array}{c}\text { Year of } \\
\text { initial } \\
\text { training } \\
\text { with }\end{array}$ & $\begin{array}{c}\text { Pseudonym of } \\
\text { school friend for } \\
\text { peer comparison }\end{array}$ \\
\hline SW1 & Silkweaver Ms Muy & 35 & F & 2003 & 1999 & Sothavy (F) \\
SW2 & Silkweaver Ms Pi & 38 & F & 2003 & 1999 & Dorina (F) \\
SW3 & Silkweaver Ms Bey & 38 & F & 2003 & 1999 & Chanthou (F) \\
SW4 & Silkweaver Mr Buon & 37 & M & 2003 & 1999 & - \\
SM5 & Stonemason Mr Pram & 29 & M & 2012 & 2007 & Khim (F); Dara \\
SM6 & Stonemason Mr Prammuy & 31 & M & 2007 & 2007 & Samnang (M) \\
\hline
\end{tabular}

Source: Artisans Angkor personnel records. 


\subsection{Limitations}

In total I have probably not stayed in Doun On for more than two months over a 20 -year period. Thus, whilst this gives some familiarity and a long-term perspective, it remains a limited amount of time and would fall short of the sort of emic perspective that could be provided by longer stays and deeper engagement in village life. The reliance on comparisons is valid to the extent that people are familiar with each other's lives, which they certainly are to an extent, but as others have noted in relation to Khmer villages in Cambodia, people will have much better knowledge of their own household members' activities, than of other households (see for example Ovesen et al. 1996). Finally, while some analysis was conducted iteratively in the field, the post-fieldwork analysis and writing was conducted in another country (Sweden) and in another language (English), and therefore just as the fieldwork was enriched by an immersion in context and exposure to different voices, the subsequent analysis and writing was impoverished by the absence of those elements.

\section{THE RESEARCH SETTING}

\subsection{Siem Reap province and Artisans Angkor social enterprise}

The social enterprise Artisans Angkor had its roots in a French development assistance project Ecoles de Formation Professionnelle (CEFP), which trained young Cambodians in traditional arts and crafts. The survival of these crafts had been put under pressure by prolonged insecurity from the 1970s to the 1990s, and especially during the repression and mass murder of the 1975-1979 period of Democratic Kampuchea (Chandler 2008). After it became clear that the trainees had difficulty in finding work with their newly acquired skills, a 1998-2001 European Union project called REPLIC transformed the training programme into a semi-public company producing and selling high-quality souvenirs. By 2008 the enterprise was self-funding (Bolster/ Brimble 2008: 290). Berthon (2019) provides a detailed history of Artisans Angkor's post-colonial attempt to reinvent Khmer traditions. As a social enterprise, Artisans Angkor has sought to foster workers' rights both by encouraging trade union membership, and through introducing a workers' share scheme that enables workers to earn a dividend when the company makes a profit, and also to constitute an association which owns a 20 per cent stake in the business. By 2017 Artisans Angkor employed 800 trained artisans at 48 rural workshops distributed through the Siem Reap countryside. In addition, a further 300 employees were involved in supply-chain logistics, administration and sales and marketing (Berthon 2019). The 800 artisans earned salaries of between US\$135 and US\$235 per month at the time of the research in 2017, as well as receiving sick pay, paid maternity leave, accident insurance and a pension scheme. On their website, Artisans Angkor describe their social mission in the following terms:

Artisans Angkor has developed from the ambitious belief that it is possible to revive ancient Cambodian Arts \& Crafts while improving the lives of thousands of people living in rural areas. Not only are we committed to the preservation of Cambodia's cultural legacy, but we also want to empower individuals by helping them secure their future by the means of education and welfare. (Artisans Angkor 2020) 


\subsection{Doun On village}

My previous research in Doun On, especially in 2012, gave me a good understanding of livelihood trajectories in the village (Biddulph 2015). Before the outbreak of war in 1970, livelihoods in Doun On revolved around rice farming in the wet season, supplemented by migration with livestock to the shores of the great Tonle Sap lake during the dry season. Other traditional activities included harvesting sugar from sugar palms in the dry season and weaving baskets from reeds all year round, as well as fishing and foraging in the de facto forest commons surrounding the village. When peace came in the 1990s the forests around the village were rapidly cleared, both by villagers and outsiders. Large tracts of these former commons were subsequently acquired by outsiders. In common with other rural settings in Southeast Asia described earlier, livelihoods based on farming and the harvest of local natural resources became less and less viable. Opportunities for labour migration gradually emerged in Thailand and in the provincial town of Siem Reap.

During the 1990s migration to Thailand had been extremely dangerous, as migrants would be travelling illegally, and would need to carry their earnings back home. With communications being limited, family members sometimes travelled to Thailand and were simply never seen or heard of again. Or they would be robbed (and often beaten) by smugglers, bandits or border security forces, losing all of the money they had earned and arriving home in very poor shape. A decade later, with passports, mobile communications and the ability to wire money home, migration to Thailand had become more lucrative and less risky. In 2012 only ten Doun On villagers ( 2.6 per cent of the adult population) were in Thailand, but they were remitting in the order of US $\$ 300$ per month, and in the region of 50 villagers were in the process of obtaining passports so that they could work there (Biddulph 2015: 107). By the time of the current research, however, Thailand was no longer the de facto alternative or supplement to village-based activities. Only one man was reported to be in Thailand, working on road maintenance. He was currently remitting US\$250 per month of a US $\$ 300$ salary. However, as an indication of the difficulties that are still associated with cross-border labour migration, he had previously been expelled from the country when looking for work, and his son had also spent seven months in prison there when his passport was found to be incorrect (Interview 19).

The reduced attraction of migration to Thailand between 2012 and 2017 was largely explained by a tourism-driven construction boom in Siem Reap town. In 2012 there were mostly lower-paid jobs in Siem Reap; by 2017 it was possible for an unskilled labourer (kamakar) to earn US\$5 per day and a skilled worker (cheang) to earn US\$10 per day, although it was much more difficult for a woman to be recognized as a skilled worker (Interview 16). Improved roads and the availability of credit to buy motorcycles has made it easier for people to work on construction sites in Siem Reap but come home to the village in the evening (Interview 9). For some villagers, construction is seen as dangerous.

Other work in Siem Reap is easier than construction but lower paid, including hotel cleaning, waiting, motorcycle taxi or car-wash worker. A handful of Doun On villagers have progressed from such jobs, largely by learning English, to get betterpaid jobs and fully establish themselves with more comfortable, urban or peri-urban lifestyles. 


\section{RESULTS: THE ARTISANS ANGKOR WORKERS AND THEIR DIRECT PEERS}

The results are presented in the form of short, present-tense, narrative comparisons of the livelihoods of the Artisans Angkor workers and their direct peers. The implications of these results are then discussed in the concluding section of the article.

\subsection{Comparison 1}

Ms Muy has been a silkweaver with Artisans Angkor since 1999. She married a soldier shortly afterwards. Her husband is stationed in a border province. At US\$200 per month his salary is a little better than hers, but she reports that his visits home are infrequent and his salary does not always enter the household. They have two children, their daughter attends high school at the district town $10 \mathrm{~km}$ away while their son is at the local primary school. They are one of a handful of households with two-storey brick houses in this village of 250 households. A combination of school costs and microfinance loan repayments, incurred to cover house construction costs and medical bills for a period of illness her husband had a few years ago, mean that the household outgoings seem to be greater than its incomes. She is sure there must be other people in the village with better jobs than her, but she cannot think of anybody. She imagines she will still be working with Artisans Angkor if I come back in ten or even 20 years.

Ms Muy's old friend Sothavy finished school at the same time as her. Sothavy's husband is a little older - a former monk who handcrafts books of religious stories and sayings and sells them, while her two children are a little younger, both of whom still attend primary school in the village. She compares her own way of earning a living with employment at Artisans Angkor:

'S': As far as I can work out I think that they are better off than I am. I applied to work for them as well, but I was too small. I was the same age as 'Muy', but when we applied she was larger, whilst I was the smallest of everybody. So I could not join.

RB: So they considered height?

'S': At that time they had an age limit. I can't remember what it was. But I was the right age, but my bones were small so I could not lie about my age so I could not join. The work is very different. I would like to have wages like them but it has not been possible. I don't know where I could go to get a regular wage. I have to find food to eat on a day to day basis. I trade baskets, I work as a wedding cook, I contact with NGOs, I farm rice, all to get a little money.

\subsection{Comparison 2}

Ms Pi is three years older than Ms Muy. She had only three years of primary education, and five years passed after she left school before she began working with Artisans Angkor. In that time she had lived at home doing farm work, house-work and in any spare time she weaved reed baskets at home. She had never thought of going anywhere to work outside the village. Her husband, similarly, has always lived and worked in the village, farming rice in the wet season, tapping sugar from palm trees in the dry season and fishing whenever and wherever he could. Ms Muy earns US\$170 per month and she reports this as their main income. Amongst her seven siblings are 
two farming brothers who she says are much better off than she is, because they are good at raising and trading buffalo.

RB: If you think of different people who you know. You have work at Artisans. Do you know other people who have other work, work which you think is better than working at Artisans?

Pi: There is only Artisans which is good work like this. It is in the shade. I've never done any other sort of work though.

RB: If you think of people who work in construction, or in Thailand?

Pi: I know people who work in Siem Reap or who have been to Thailand.

RB: If you think of those sorts of work, are they better or is the work with Artisans better?

Pi: This work is better. Working nearby means we don't have to go far, not like those who go to Siem Reap or to Thailand. We don't have to go far like them.

Ms Pi's old schoolfriend Dorina also finished primary school after three years, also took the test at Artisans Angkor, but was not selected. She is also married to a man from the village. She and her husband do not travel to the Tonle Sap flood plain; if they have buffalo they pay somebody else to take them there in the dry season. They both live and work in the village, her husband's activities are similar to Ms Pi's husband, but he also has a speciality of catching frogs and selling their meat, which supplements their income. Dorina became ill after the birth of the first of her four children, and has not been able to do really hard work since. In fact, she reports that her treatment at the provincial hospital was the only time in her life that she had travelled the $30 \mathrm{~km}$ to the provincial town. Dorina says that their oldest child, a 16-year-old girl, studied to year 9, which is unusual for children in Doun On, and especially for girls. However (in contrast with Ms Muy's daughter above), eventually the costs of her schooling were too much for the family and she had to leave school so that she could help with the work at home. Ms Pi thinks her life would have been much better if she had worked for Artisans Angkor.

\subsection{Comparison 3}

Ms Bey is married to Mr Buon (see Comparison 4), so they are the one household in the village with two Artisans Angkor employees in it. She had two years of primary school education and then worked at home with her parents for a couple of years. She especially remembers gathering firewood during that time and using it to boil the palm sugar her father collected to make palm wine. She and her husband have a two-storey pink-brick house. They are currently repaying a three-year US\$3000 loan that they took out for the last phase of construction. The monthly instalments are US\$120. She describes many benefits of working at Artisans Angkor, which all relate to some degree to being able to live at home with her family while working. When we interview her, she is on parental leave following the birth of her fourth child. Artisans Angkor offers 15 days on full pay and 90 days on half pay for each child, so in total she has received over 12 months of paid parental leave in the course of her service. She says that many of the women from the village who had similar abilities to her are now away working in garment factories in Phnom Penh, but she says that she is not sure how things are working out for them.

One of Ms Bey's schoolfriends who is still based in the village is Ms Chanthou. She and her husband have for many years alternated between working on construction 
sites in Thailand during the dry season and coming home to farm their rice fields during the wet season. They have built a house in the village, which her parents take care of. Their mobile lifestyle is made easier by the fact that they have no children. Recently they have begun working on construction sites in Siem Reap instead of Thailand. Women get paid less than men, typically 20000 to 22000 riels (between US\$5 and US\$5.50) per day, so if Chanthou works 25 days in a month she will earn between US\$125 and US\$140. This is comparable with Ms Bey's US\$135, but without the health insurance, maternity leave and other benefits that Artisans Angkor workers receive. We interview Chanthou's sister-in-law who is not sure about the salaries, but has a clear idea of which sort of work is preferable: 'Weaving is better than construction. Construction they work high, high up' (Interview 12).

\subsection{Comparison 4}

Mr Buon is from a nearby village where he had six years of schooling. After that he travelled to Thailand with his mother to work on a sugar cane plantation. Shortly after returning home he married Ms Bey, moved to Doun On and began working at Artisans Angkor. Unlike most of the other Artisans Angkor employees in the village he shows a clear understanding of the share scheme, remembering how he paid US\$7 a month from his salary up to a total of US\$168 to obtain ten shares in the company, which pay dividends in the years that the company makes a profit. He is not currently a member of either of the two labour unions active at Artisans Angkor but he is well informed about their activities and (unlike his wife) thinks he may join in the future.

Having moved to Doun On to get married, he cannot nominate another villager with whom he was at school. He thinks many of his school friends worked in construction initially in Thailand and now in Siem Reap, and will be earning more than him. He earns US\$145 per month with Artisans Angkor. If he compares himself with his younger brother who is working as a tuk-tuk driver at the district town, he thinks that his younger brother's job is not as good. However, he thinks that there are other people in the village who perhaps have better jobs than him:

RB: If we think about people you know. You work at Artisans. Do you know anybody in this village who you think, 'they probably have a better job than we do'?

PY: I never go anywhere so I don't know anybody.

RB: You know people here in the village!

B: From what I have heard, they work in construction. From what I have heard they have a better job than we do.

RB: So if you have heard that maybe construction work is better than working with Artisans Angkor, why do you still work with Artisans, and have not switched to working with construction?

B: Because I don't know how to do construction work.

RB: But couldn't you learn?

B: I could, but I would not be able to earn as much money as they do from the start.

RB: If they work in construction, how much can they get paid?

B: According to what I have heard from villagers, for example my own nephew, he gets 10 dollars a day. 
RB: So that is more than working for Artisans?

B: He is a skilled worker. Those who are just labourers can only earn maybe US\$6 or US\$7.

Mr Buon is, however, the only one of the Artisans Angkor workers in the sample who does not expect to stay with the company in the future. He is contemplating work with his wife's sister and her husband as employees of a company that sells bottled water. He would be travelling around the province delivering to villages.

\subsection{Comparison 5}

Mr Pram initially began with Artisans Angkor in 2007 but after about a year he was made redundant. However, when they recruited again in 2012 he successfully applied to rejoin. His parents have six children including his sister who is the silkweaver Ms Muy (see comparison 1 above). Some of their siblings work in the village doing traditional work such as rice farming, basketweaving and buffalo raising. Others work in construction in Siem Reap, and one son-in-law has a job as a clerical assistant to the commune secretary, which pays US $\$ 125$ per month. Their parents judge that Muy and Pram are the most prosperous of their children, with the best jobs, and they wish that their other children could also work for Artisans Angkor.

Mr Pram earns US\$187 a month with Artisans Angkor and also contributes to the household by doing odd jobs in the evening and working on the rice fields at the weekend. He lives with his wife and widowed mother-in-law who sell meat, fish, vegetables and other household supplies in front of their house in the village. $\mathrm{Mr}$ Pram's sister-in-law received beautician training from a Korean NGO that helps orphans. She worked for a time as a beautician in the provincial town. There she met and married a construction worker. They have moved back to the village and have built a large brick house where they live and where she has started her own business as a beautician and hairdresser. They seem to be wealthier than Mr Pram and his family who live in a smaller house behind theirs.

During the time Mr Pram was laid off from Artisans Angkor he did not work in Thailand or Siem Reap because he preferred to be with his family. During that time he never had much money and sometimes had to borrow from his mother who used to criticize him bitterly for this. He says that if I come back in five years' time, or even in 20 years' time, he still expects to be working for Artisans Angkor.

Mr Pram studied to year 9. Among the few of his peers who also did that were Ms Khim (with whom he used to cycle the $10 \mathrm{~km}$ to school every day) and a relative of his mother-in-law, Mr Dara, who studied in the year below.

Khim explains that at the time that Artisans Angkor were recruiting south of the village, there was a new golf course recruiting caddies north of the village. So while Mr Pram applied to Artisans Angkor she applied to the golf course. She worked as a caddy for three years and had entertaining tales of running after golf balls, and communicating with players from different countries using her limited English. After three years she became pregnant, and, at the same time, got malaria. As a result she never returned to caddying again. She says that now she would consider going back to caddying if she could lose some weight and get fit, but would much prefer to have a job with Artisans Angkor like Mr Pram. She asks if we have any information about when they might be recruiting again.

Mr Dara left the village shortly after finishing school in order to work in a souvenir workshop in Siem Reap town. His starting salary was US\$50 per month, which increased eventually to US $\$ 100$. At the souvenir workshop he met a woman who came 
from a village east of Siem Reap. They married and now have young children. He has stopped working at the souvenir workshop and is instead working on construction sites and travelling home to his family every evening. Mr Pram's mother-in-law thinks that Dara would have been better off if he had been able to have a job with Artisans Angkor.

Working in construction is very hard work. It is very hard work and it is very high - you can be working on buildings two or three storeys. So it is harder and more unpleasant. I would be afraid to work in construction. Even if the pay was more than one hundred I would not choose to do it. Working at Artisans is easier. You are working in the shade. It is not like construction. Sometimes there are falls. A girl from this village fell. She was fetching cement and she fell and she was knocked unconscious. (Interview 4)

\subsection{Comparison 6}

Mr Prammuy has been with Artisans Angkor since 2007 and earns US\$217 per month. $\mathrm{He}$ is the younger brother of silkweaver Ms Pi (see comparison 2). He and his wife are establishing a new house on the outskirts of the village. It is by the road and they expect others to move here so it will eventually be a good place for her to sell general supplies and fuel, although at present it is quiet and they largely depend on his income to support themselves and their two young children. Mr Prammuy does not have any thoughts of getting other work. He says that he has spent ten years becoming a good stonemason and would not want to start a new trade at a low level.

Mr Samnang went to school with Mr Prammuy. He says that he only heard that Artisans Angkor were looking for new employees afterwards, so was not able to apply for that work. He is still single and has worked in construction and also on his parents' rice fields. He used to travel to another province to do construction work, but now his father is ill so he works in Siem Reap so that he can be at home and take care of his parents' livestock.

As a construction worker he works with different building foremen at different times, but for each job he usually goes with three or four other people from the village, so he is usually with people he knows. His daily rate is US\$7.50:

RB: And in a month, do you work maybe 30 days, or maybe only 10-15 days?

VV: It varies, but in a month, maybe 25 or 26 days of work.

RB: And the construction work, is it easy or difficult or what?

VV: For me, I think it is easy. It is normal.

RB: Do you have to climb up high?

VV: I have never had to work up high. I just work on normal size houses, nothing with a high roof or anything.

RB: So you haven't had accidents?

VV: No.

He says that he finds it difficult to compare construction work with working for Artisans Angkor. He thinks that the salary with Artisans Angkor is slightly better. However, for construction workers there is more flexibility 'Stone carving earns more. And they rest every Sunday. But for me, I can rest any day I like'. His relatives, sitting within earshot, joke that Artisans Angkor is better for people who really want to work, 
and construction is better for people who want more freedom to go out and have fun (Interview 8).

\section{CONCLUDING DISCUSSION}

Our results show all of our respondents agreeing that workers with the tourism social enterprise (TSE) Artisans Angkor have better livelihoods than their direct peers. The reasons for this do not directly relate to salary, but are variously related to safety and comfort at work, lack of anxiety about economic concerns, and the ability to be at home with young families. The Artisans Angkor workers are not the wealthiest in the village - a handful of other households have through various business successes fared better economically. The benefits of employment with Artisans Angkor seem to a large degree to be at the household level. There are no significant economic multiplier effects nor any sign that the livelihood trajectories of Artisans Angkor workers have had implications for the wider village community. These results are now discussed in the context of the relationships between tourism and livelihoods in Southeast Asia, and the social impacts of TSEs.

\subsection{Tourism and livelihoods in Southeast Asia}

The literature on tourism and rural livelihoods in Southeast Asia tends to discuss a deagrarianizing countryside where traditional farming and fishing activities are of declining importance and the expansion of tourism in an increasingly interconnected world provides a potential new source of activities and incomes (Fabinyi 2010; Lasso/Dahles 2018; Turner 2012). In the case of Doun On, in common with many accounts of Southeast Asian rural development, the broad trajectories of modernization and change have been welcomed notwithstanding some environmental and social costs (cf. Rigg 2015).

Tourism's influence in Doun On extended well beyond the five households of the six Artisans Angkor workers. In the five years between our previous research into livelihoods in the village and the fieldwork for this study, a construction boom in Siem Reap town had provided relatively well-paid informal casual labour that appeared to have become the main supplement to village-based livelihood activities for Doun On households. To the extent that construction is dependent not only on tourism, but on rapid tourism expansion, it may not represent a long-term option. Even before the COVID-19 crisis, the CEO of Artisans Angkor was reporting decreasing visitor numbers, especially related to rumours of crowding and over-tourism (Clergeant 2018). This may constitute a levelling of the 20-year boom as the Siem Reap destination reaches maturity (Butler 2000). If so, Doun On households will revert to dependence on either less lucrative options in Siem Reap town, or more risky options in Thailand, with the disruptions to family life that these entail. In such a scenario, the sort of steady jobs offered by Artisans Angkor will be even more valued than reported by our respondents here.

Artisans Angkor's decentralized approach appears from the case of Doun On to have succeeded in stimulating the sort of 'rural industries' that have been called for by other tourism and livelihoods studies (Kausar/Nishikawa 2010), and in a way that supports a good fit between formal employment and other livelihood activities in the workers' households. The livelihood benefits of working with Artisans Angkor in the future will, however, necessarily be different for reasons of household livelihood 
trajectory (De Haan/Zoomers 2005). The workers in our case were recruited as young adults and are now approaching middle age. They have been able to stay at home and have steady incomes during their children's school years. As their children become adults and start having children of their own, the household contexts for employment will change and a new set of comparisons will be required to understand those.

\subsection{TSE social innovation and scale}

The broader social enterprise literature seeks innovations (like group-secured microfinance loans) which can 'jump scale' by developing goods or services that can address widespread social needs (Dees 2008). A conventional souvenir production business model does not really promise that sort of up-scaling, although the decentralization of production operations from an urban tourism centre out into a rural hinterland for reasons of spatially equitable development may be an innovation that can be replicated. The TSE literature meanwhile is more focused on issues of social innovation for community development (Aquino et al. 2018; Dahles et al. 2020). Providing work for six members of five households (in a village of 250 households), in what Dahles et al. (2020) would characterize as a 'cash cow' engagement, does not correspond to the community development approach.

Rather, the social innovation at the core of the Artisans Angkor approach is to provide empowerment through creating decent work. It treats the rural poor not as potential entrepreneurs, but rather as workers (cf. Bromley 2009). The workers in this study have been empowered in the sense that their freedoms have been expanded; they have been able to work in comfortable, safe conditions, sickness and pregnancy have become far more easily managed, and they have been able to provide better schooling and better home lives for their children.

Artisans Angkor also sought to empower workers by supporting share ownership and union membership. This was a notable innovation in an industry where labour rights and decent work are often elusive (cf. Bianchi/de Man 2020; Cañada 2018). In our interviews, share-holding and union membership were only mentioned when we specifically asked about them. Within our sample, therefore, the TSE investment in worker agency and identity did not seem to have yielded much at the individual level. However, this innovation may be worthy of further study, perhaps through ethnographic accounts of union meetings, or an interview strategy that focuses on union organizers. This would give more specific attention to worker agency in a tourism context, and would also provide a point of comparison to other companies and sectors in Cambodia where there appears to be a more hostile environment for organized labour (Lawreniuk 2020).

\subsection{Further qualitative research}

This research, encompassing as it did just one week of field interviews, has illustrated how qualitative methods can be used to provide a rapid and contextualized assessment of tourism's livelihood impacts. However, with more time we could have learned much more about the meanings (including emotional/affective implications) of many aspects that were presented quite simply and dispassionately. These included issues relating to whether or not children could continue their education and whether or not parents could be with their children. In the current transcripts we have short one-sentence statements about these situations. Accepting these statements in this truncated form risks reproducing acknowledged weaknesses in the livelihoods 
approach: a tendency to reduce life to bare economics and logistics, and therefore overlook vital aspects of women's and men's experiences of their lives and livelihoods (Scoones 2009). Similarly, some interview data suggested that the trade-offs between the disciplines of a steady job and the security it provides, and between casual work and the freedom it provides, are gendered in particular ways that tend to reproduce inequalities in how household members share responsibilities. A more in-depth analysis of such dynamics might yield valuable recommendations on how Artisans Angkor and other TSEs could incorporate feminist perspectives into their approaches (cf. Nimble 2019; Xu 2018).

\section{ACKNOWLEDGEMENTS}

FORMAS, a Swedish research board for sustainable development, funded this research through grant number 2015-01540 for a project entitled 'Social Enterprise in Scandinavia and Southeast Asia'. Two successive Chief Executive Officers at Artisans Angkor, Vincent Drouillard and Pierre Andre Romano, and many of their colleagues in Siem Reap, Pourk and Don Keo were welcoming and friendly and facilitated our work. Ly Sinath, as research associate, provided good advice and assisted with transport and logistics. Houth Heab and other villagers in Doun On were goodhumoured, hospitable and generous in sharing their experiences. Thank you all, and good luck with overcoming the difficulties created by the current situation.

\section{REFERENCES}

Aquino, R.S., Lück, M., Schänzel, H.A. (2018): A conceptual framework of tourism social entrepreneurship for sustainable community development, in: Journal of Hospitality and Tourism Management, 37, 23-32.

Artisans Angkor (2020): Artisans Angkor: home made in Cambodia, URL: http:// www.artisansdangkor.com/ (accessed 9 May 2020).

Baker, K., Coulter, A. (2007): Terrorism and tourism: the vulnerability of beach vendors' livelihoods in Bali, in: Journal of Sustainable Tourism, 15, 249-266.

Bakker, M., Messerli, H.R. (2017): Inclusive growth versus pro-poor growth: implications for tourism development, in: Tourism and Hospitality Research, 17, 384-391.

Berthon, M.A. (2019): Artisans Angkor: reclaiming Cambodian silk crafts under French patronage (1992-2017), in: Journal of Textile Design Research and Practice, 7, 78-103.

Bianchi, R.V., De Man, F. (2020): Tourism, inclusive growth and decent work: a political economy critique, in: Journal of Sustainable Tourism, 1-19, URL: https://www.tandfonline. com/doi/abs/10.1080/09669582.2020.1730862?journalCode=rsus20.

Biddulph, R. (2010): Geographies of Evasion: The Development Industry and Property Rights Interventions in Early 21 st Century Cambodia, $\mathrm{PhD}$, University of Gothenburg.

Biddulph, R. (2015): Limits to mass tourism's effects in rural peripheries, in: Annals of Tourism Research, 50, 98-112.

Biddulph, R. (2018): Social enterprise and inclusive tourism: five cases in Siem Reap, Cambodia, in: Tourism Geographies, 20, 610-629.

Blaikie, P., Cameron, J., Seddon, D. (2002): Understanding 20 years of change in West-Central Nepal: continuity and change in lives and ideas, in: World Development, 30, 1255-1270.

Bolster, P., Brimble, P. (2008): Cambodia: corporate social responsibility and the Cambodia Business Initiative in Rural Development (C-BIRD), in: Küsel, C., Maenner, U., Meissner, R. (eds), The Social and Ecological Market Economy: A Model for Asian Development?, Eschborn: Deutsche Gesellschaft für Technische Zusammenarbeit, 287-299. 
Bromley, D.W. (2009): Formalising property relations in the developing world: the wrong prescription for the wrong malady, in: Land Use Policy, 26, 20-27.

Butler, R.W. (2000): The resort cycle two decades on, in: Faulkner, B., Moscardo, G., Laws, E. (eds), Tourism in the 21st Century: Reflections on Experience, London and New York: Continuum, 284-299.

Cañada, E. (2018): Too precarious to be inclusive? Hotel maid employment in Spain, in: Tourism Geographies, 20, 653-674.

Chambers, R. (1997): Whose Reality Counts? Putting the First Last, London: ITDG Publishing.

Chambers, R., Conway, G. (1992): Sustainable rural livelihoods: practical concepts for the 21st century, Discussion Paper, Brighton: Institute of Development Studies.

Chandler, D. (2008): A History of Cambodia (Fourth Edition), Chiang Mai: Silkworm.

Chell, E., Nicolopoulou, K., Karataş-Özkan, M. (2010): Social entrepreneurship and enterprise: international and innovation perspectives, in: Entrepreneurship, Regional Development, 22, 485-493.

Clergeant, R. (2018): Cambodge: Stop ou... Angkor!, in: Paris Match, 9 September.

Dahles, H., Khieng, S., Verver, M., Manders, I. (2020): Social entrepreneurship and tourism in Cambodia: advancing community engagement, in: Journal of Sustainable Tourism, 28, 816-833.

Dees, J.G. (2008): Philanthropy and enterprise: harnessing the power of business and social entrepreneurship for development, in: Innovations: Technology, Governance, Globalization, $3,119-132$.

De Haan, L., Zoomers, A. (2005): Exploring the frontier of livelihoods research, in: Development and Change, 36, 27-47.

Desa, G., Koch, J.L. (2014): Scaling social impact: building sustainable social ventures at the base-of-the-pyramid, in: Journal of Social Entrepreneurship, 5, 146-174.

Dey, P., Steyaert, C. (2010): The politics of narrating social entrepreneurship, in: Journal of Enterprising Communities: People and Places in the Global Economy, 4, 85-108.

Fabinyi, M. (2010): The intensification of fishing and the rise of tourism: competing coastal livelihoods in the Calamianes Islands, Philippines, in: Human Ecology, 38, 418-427.

Kausar, D.R., Nishikawa, Y. (2010): Heritage tourism in rural areas: challenges for improving socio-economic impacts, in: Asia Pacific Journal of Tourism Research, 15, 195-213.

Kickul, J., Lyons, T.S. (2016): Understanding Social Entrepreneurship: The Relentless Pursuit of Mission in an Ever Changing World, Abingdon, UK: Routledge.

Laeis, G.C.M., Lemke, S. (2016): Social entrepreneurship in tourism: applying sustainable livelihoods approaches, in: International Journal of Contemporary Hospitality Management, 28, 1076-1093.

Lasso, A., Dahles, H. (2018): Are tourism livelihoods sustainable? Tourism development and economic transformation on Komodo Island, Indonesia, in: Asia Pacific Journal of Tourism Research, 23, 473-485.

Lawreniuk, S. (2020): Intensifying political geographies of authoritarianism: toward an antigeopolitics of garment worker struggles in neoliberal Cambodia, in: Annals of the American Association of Geographers, 110, 1174-1191.

Lund, C. (2014): Of what is this a case? Analytical movements in qualitative social science research, in: Human Organisation, 73, 224-234.

Mao, N., Grunfeld, H., Delacy, T., Chandler, D. (2014): Agriculture and tourism linkage constraints in the Siem Reap-Angkor region of Cambodia, in: Tourism Geographies, 16, 669-686.

Ministry of Tourism (2019): Tourism statistics report year 2018, in: Department, S.A.T.I. (ed.), Tourism Statistics Report Year 2018, Phnom Penh: Royal Government of Cambodia, 8.

Mitchell, J., Ashley, C. (2010): Tourism and Poverty Reduction: Pathways to Prosperity, London: Earthscan.

Mody, M., Day, J. (2017): Heroic messiahs or everyday businessmen? The rhetoric and the reality of social entrepreneurship in India, in: Sheldon, P.J., Daniele, R. (eds), Social Entrepreneurship and Tourism: Philosophy and Practice, Cham, Switzerland: Springer International Publishing, 207-220. 
Newby, J., Cramb, R., Sakanphet, S. (2014): Forest transitions and rural livelihoods: multiple pathways of smallholder teak expansion in Northern Laos, in: Land, 3, 482-503.

Nicholls, A., Teasdale, S. (2017): Neoliberalism by stealth? Exploring continuity and change within the UK social enterprise policy paradigm, in: Policy, Politics, 45, 323-341.

Nimble, N. (2019): Community-based tourism development as gendered political space: a feminist geographical perspective, in: Journal of Interdisciplinary Feminist Thought, 11, $1-29$.

Ovesen, J., Trankell, I.-B., Öjendal, J. (1996): When Every Household is an Island, Stockholm and Uppsala: Sida/University of Uppsala, URL: https://www.diva-portal.org/smash/get/ diva2:71286/FULLTEXT01.pdf.

Ren, C.B. (2016): Qualitative research in tourism, in: Jafari, J., Xiao, H. (eds), Encyclopedia of Tourism, Cham, Switzerland: Springer International, 1-4.

Rigg, J.D. (2015): Challenging Southeast Asian Development: The Shadows of Success, Abingdon, UK: Routledge.

Rigg, J., Salamanca, A. (2017): Aggregate trends, particular stories: tracking and explaining evolving rural livelihoods in Southeast Asia, in: McGregor, A., Law, L., Miller, F. (eds), Routledge Handbook of Southeast Asian Development, Abingdon, UK: Routledge, 39-52.

Saebi, T., Foss, N.J., Linder, S. (2018): Social entrepreneurship research: past achievements and future promises, in: Journal of Management, 45, 70-95.

Scheyvens, R., Biddulph, R. (2018): Inclusive tourism development, in: Tourism Geographies, 20, 589-609.

Scoones, I. (1998): Sustainable rural livelihoods: a framework for analysis, IDS Working Paper 72, Brighton: Institute for Development Studies.

Scoones, I. (2009): Livelihoods perspectives and rural development, in: Journal of Peasant Studies, 36, 171-196.

Sharpley, R. (2016): Poverty alleviation through tourism: a comprehensive and integrated approach, in: Tourism Management, 56, 207-208.

Sharpley, R., Mcgrath, P. (2017): 7 Tourism in Cambodia: opportunities and challenges, in: Brickell, K., Springer, S. (eds), The Handbook of Contemporary Cambodia, Abingdon, UK: Routledge, 87-98.

Sheldon, P.J., Daniele, R. (eds) (2017): Social Entrepreneurship and Tourism: Philosophy and Practice, Cham, Switzerland: Springer International.

Shen, F., Hughey, K.F.D., Simmons, D.G. (2008): Connecting the sustainable livelihoods approach and tourism: a review of the literature, in: Journal of Hospitality and Tourism Management, 15, 19-31.

Smith, W., Darko, E. (2014): Social enterprise: constraints and opportunities - evidence from Vietnam and Kenya, Report, London: Overseas Development Institute, URL: https:// www.odi.org/sites/odi.org.uk/files/odi-assets/publications-opinion-files/8877.pdf.

Tao, T.C.H., Wall, G. (2009): Tourism as a sustainable livelihood strategy, in: Tourism Management, 30, 90-98.

Terry, G., Hayfield, N., Clarke, V., Braun, V. (2017): Thematic analysis, in: Willig, C., Rogers, W. (eds), The Sage Handbook of Qualitative Research in Psychology, Newbury Park, CA: SAGE Publishing, 17-37.

Turner, S. (2012): Making a living the Hmong Way: an actor-oriented livelihoods approach to everyday politics and resistance in upland Vietnam, in: Annals of the Association of American Geographers, 102, 403-422.

Von der Weppen, J., Cochrane, J. (2012): Social enterprises in tourism: an exploratory study of operational models and success factors, in: Journal of Sustainable Tourism, 20, 497-511.

Winter, T. (2008): Post-conflict heritage and tourism in Cambodia: the burden of Angkor, in: International Journal of Heritage Studies, 14, 524-539.

Xu, H. (2018): Moving toward gender and tourism geographies studies, in: Tourism Geographies, 20, 721-727.

Yunus, M., Moingeon, B., Lehmann-Ortega, L. (2010): Building social business models: lessons from the Grameen experience, in: Long Range Planning, 43, 308-325. 
92 Journal of Qualitative Research in Tourism, Vol. 1 No. 1

\section{APPENDIX 1}

Table A1 Doun On village interviews, 22-27 November 2017

\begin{tabular}{|c|c|c|c|}
\hline Interview no & Purpose & $\begin{array}{c}\text { Recorded and } \\
\text { transcribed }\end{array}$ & Date \\
\hline 1 & SW1 & $\mathrm{Y}$ & 25 November 2017 \\
\hline 2 & SW1 comparison & $\mathrm{Y}$ & 25 November 2017 \\
\hline 3 & SM5 & $\mathrm{N}$ & 22 November 2017 \\
\hline 4 & SM5 mother-in-law & $\mathrm{Y}$ & 23 November 2017 \\
\hline 5 & SM5/SM1 parents & $\mathrm{N}$ & 23 November 2017 \\
\hline 6 & SM5 comparison & $\mathrm{N}$ & 23 November 2017 \\
\hline 7 & SM6 & $\mathrm{Y}$ & 26 November 2017 \\
\hline 8 & SM6 comparison & $\mathrm{Y}$ & 27 November 2017 \\
\hline 9 & SW4 & Y & 25 November 2017 \\
\hline 10 & SW3 & $\mathrm{N}$ & 27 November 2017 \\
\hline 11 & SW3 & Y & 27 November 2017 \\
\hline 12 & SW3 comparison's sister-in-law & Y & 24 November 2017 \\
\hline 13 & SW2 & Y & 26 November 2017 \\
\hline 14 & SW2/SM6 mother & $\mathrm{Y}$ & 26 November 2017 \\
\hline 15 & SW2 comparison & $\mathrm{Y}$ & 25 November 2017 \\
\hline 16 & Construction work & $\mathrm{Y}$ & 26 November 2017 \\
\hline 17 & Thai labour migration & Y & 26 November 2017 \\
\hline 18 & Traditional silkweaving & $\mathrm{N}$ & 26 November 2017 \\
\hline 19 & Dry season flood plain migration & $\mathrm{N}$ & 27 November 2017 \\
\hline 20 & SM6 wife & $\mathrm{Y}$ & 24 November 2017 \\
\hline
\end{tabular}

